\title{
ОСОБЛИВОСТІ ТЕХНОЛОГІЇ ПЛАВЛЕНИХ СИРІВ ЛІКУВАЛЬНО-ПРОФІЛАКТИЧНОГО СПРЯМУВАННЯ ІЗ КРІОПОРОШКОМ «БУРЯК»
}

\author{
Гачак Ю. Р., Гутий Б. В.
}

\section{ВСТУП}

Сучасні тенденції розвитку харчових технологій останніми роками спрямовані на виробництво конкурентно-здатного асортименту, призначеного для забезпечення раціонального, повноцінного збалансованого - 3 елементами функціонального, оздоровчого і масового харчування ${ }^{1,2}$. Сучасна складна екологічна обстановка в Україні вимагає створення продуктів, в тому числі і плавлених сирів, 3 різноманітними наповнювачами та біодобавками, в тому числі і з лікарськими рослинами та спеціями, ${ }^{3,4,5}$. Як відомо, лікувальні властивості харчових лікарських рослин зумовлені наявністю в них біологічно активних речовин, включаючи різноманітні вітаміни, мікро-, макроелементи і різного роду ферменти ${ }^{6}$.

${ }^{1}$ Bilyk, O. Substantiation of the method of protein extraction from sheep and cow whey for producing the cheese «Urda» / O. Bilyk, N. Slyvka, B. Gutyj, H. Dronyk, O. Sukhorska. Eastern-European Journal of Enterprise Technologies. Харків. 2017. В. 3. № 11(87). С. 18-22.

2 Kaminarides, S. Effect of added milk and cream on the physicochemical, rheological and volatile compounds of Greek whey cheeses / S. Kaminarides, K. Nestoratos, T. Massouras. Small Ruminant Research. Volume 113, Issues 2-3, July 2013, Pages 446-453. DOI https://doi.org/10.1016/j.smallrumres.2013.04.009.

${ }^{3}$ Gutyj, B. The elaboration of cheese masses of therapeutic and prophylactic direction with cryoadditive "Pumpkin" / B. Gutyj, Y. Hachak, J. Vavrysevych, V. Nagovska. “EUREKA: Life Sciences”. 2017. № 1, 19-26.

4 Gutyj B. The influence of cryopowder "Garbuz" on the technology of curds of different fat content / B. Gutyj, Y. Hachak, J. Vavrysevych, V. Nagovska. EasternEuropean Journal of Enterprise Technologies. Харків. 2017. В. 2. № 10(86). C. 20-24.

5 Гачак Ю.Р. Застосування рослинної біодобавки в технології плавлених сирів / Ю.Р. Гачак, О.Р. Михайлицька. Збірник матеріалів наукової конференції «Оздоровчі харчові продукти та дієтичні добавки: технології, якість та безпека». Київ : НУХТ, 2014. С. 31-32.

6 Гойко I., Пришепа М. Застосування кропу, черемші, базиліку у виробництві кисломолочного сиру. Збірник міжнародної науково-практичної конферениї «Оздоровчі харчові продукти та дієтичні добавки, технології, якість та безпека». Київ : НУХТ, 2014. С. 15-16. 
Актуальність використання лікарських рослин, в число яких входить і буряк у формі кріопорошку, значно зросла останніми роками. Використання продукції кріогенних технологій дозволяє ефективно переробити рослину, зберігши найбільш можливу кількість біологічно активних речовин у природному співвідношенні. При цьому їх концентрація збільшується і у десятки разів підвищується рівень засвоєння організмом ${ }^{7,8}$.

Максимально-корисної дії молочних продуктів на організм можна досягти, використовуючи ці біодобавки як наповнювачі, в тому числі і з метою лікування та профілактики шкідливої дії негативних факторів середовища 9 . В цьому плані використання кріопорошків як біодобавок до «молочної» основи, вміле їх поєднання несе у собі великі перспективи як у соціальному, так i біолого-технологічному плані ${ }^{10,11}$.

Враховуючи вищенаведене, вивчення впливу застосування нового вітчизняного кріопорошку «Буряк» в технології солодкого та соленого плавлених сирів видається нам перспективним напрямом досліджень не лише 3 погляду створення нових вітчизняних молочних продуктів лікувально-профілактичного спрямування, але й розширення традиційного асортименту молокопереробних підприємств, що виробляють аналогічну продукцію нового покоління.

${ }^{7}$ Kaminarides, S. Effect of added milk and cream on the physicochemical, rheological and volatile compounds of Greek whey cheeses / S. Kaminarides, K. Nestoratos, T. Massouras. Small Ruminant Research. Volume 113, Issues 2-3, July 2013, Pages 446-453. URL: https://doi.org/10.1016/j.smallrumres.2013.04.009.

${ }^{8}$ Turchyn I., Zalensky, M., Voychishin, A. Development of technology of cereal past with combined composition. Scientific Messenger of Lviv National University of Veterinary Medicine and Biotechnologies. 2018. Vol. 20, № 85. P. 24-28.

9 Беницька А.А., Осечко В.І., Гачак Ю.Р. Спеції в якості фітодобавок у технології молочних продуктів ЛПС. Матеріали міжнародної студентського наукової конференції ЛНУВМ БТ імені С. 3. Гюииького. 2016. Ч. 3. С. 89-90.

${ }^{10}$ Бойчак Я., Кобернюк В., Петрик Л. Нові види і форми біодобавок в технології молочних продуктів ЛПН. Дні студентської науки у ЛНУВМ та БТ імені С.3. Гжицького: Матеріали студентської конференції. Львів, 2018. С. 79-80.

${ }^{11}$ Савченкова Л.В., Акімова М.С. Вивчення токсичності кріоподрібненого порошку аронії чорноплідної. Аспекти розвитку фармацевтичних та медичних досліджень на сучасному етапі: матеріали IV Всеукраӥнської науковопрактичної конференції з міжнародною участю, м. Луганськ, 27-28 березня 2014 p. C. 105. 


\section{1. Аналіз літературних даних та постановка проблеми}

Як відзначають численні дослідники, останніми роками новітні технології молочних функціональних продуктів передусім повинні бути спрямовані на збереження корисних речовин молока, оскільки молоко $є$ природним функціональним продуктом ${ }^{12,13,14}$. В той же час стрімко зростає роль наповнювачів під час виробництва молочної продукції. Суспільство невпинно вимагає вдосконалення наявних та створення щораз нових технологій продуктів, в тому числі і плавлених сирів із їхнім нормативним чисельним складом пропонованих наповнювачів ${ }^{15,16}$. Важливе завдання наповнювачів це підвищення біологічної, харчової та технічної якості, а також цінність виготовлюваних продуктів ${ }^{17,18}$.

На цей час перевагу мають ті продукти, які здатні очищати організм від радіонуклідів, важких металів, шлаків, забезпечують його нормальне функціонування та підвищують резистентність до

${ }^{12} \mathrm{Ha}$, M. In-Depth Characterization of Sheep (Ovis aries) Milk Whey Proteome and Comparison with Cow (Bos taurus) / M. Ha, M. Sabherwal, E. Duncan, S. Stevens, P. Stockwell, M. McConnell, A. El-Din Bekhit, A. Carne. PLoS ONE. 2015. Vol. 10. Issues 10. e0139774 DOI 10.1371/journal.pone.0139774.

13 Horyuk Yu.V. Kukhtyn M.D., Perkiy Yu.B., Horyuk V.V., Semenyuk, V.I. Identification of Enterococcus isolated from raw milk and cottage cheese "home" production and study of their sensitivity to antibiotics. Scientific Messenger LNUVMBT named after S.Z. Gzhytskyj. 2016. Vol. 18, № 3(70). P. 44-48.

${ }^{14}$ Nagovska V., Hachak Y., Gutyj B., Bilyk O., Slyvka N._Influence of wheat bran on quality indicators of a sour milk beverage. Eastern-European Journal of Enterprise Technologies. 2018. Vol. 4, Issue 11 (94). P. 28-34.

${ }^{15}$ Samilyk M. Improving the technology of soft sour milk cheese by increasing biological value. Scientific Messenger of Lviv National University of Veterinary Medicine and Biotechnologies. 2017. Vol. 19, № 80. P. 33-37.

16 Сливка Н.Б. Нова рецептура плавлених сирів із ехінацеєю та страв 3 нього. Тези доповідей Всеукраӥнської науково-практичної конферениї мол. вчених $і$ студентів «Актуальні питання розвитку харчових в-в, ресторанного 2-ва і торгівлі». Харків. 2010. С. 27-89.

17 Пуківський П., Турчин І., Сливка Н., Михайлицька О. Використання рослинної сировини в технології сиркових мас. Науковий вісник Львівського національного університету ветеринарної медицини та біотехнологій імені С.3. Гжицького. 2015. Т. 17, № 4. С. 105-109.

18 Украинец А.И., Рашевская Т.А., Вашека О.Н. Морфология кристаллических элементов наноструктуры сливочного масла с криопорошками растительными пищевыми. Кинетика и механизм кристаллизации. Кристаллизация для нанотехнологий, техники и медицины : V междунар. науч. конф., 23-26 сент. 2008 г. : тезисы докл. Иваново (Россия), 2008. С. 190. 
несприятливих факторів навколишнього середовища споживачів $^{19,20}$.

Дуже перспективним $є$ збагачення молочних продуктів вітамінами та мінеральними речовинами за рахунок додавання до них рослинних біодобавок у різних агрегатних станах. Створюються нові продукти, чи так звані комбіновані, - лікувально-профілактичні продукти ${ }^{21}$.

Основними методологічними підходами до формування функціональних продуктів $\epsilon:{ }^{22}$

- технологічна сумісність дієтичних добавок 3 основними компонентами харчових систем;

- збереження біологічної активності добавок під час кулінарного обробітку і зберігання;

- поліпшення якості продукції за рахунок введення в рецептуру добавок;

- формування фізіологічної цінності продукту функціонального харчування;

- ідентифікація дієтичних добавок 3 визначеною біологічною активністю;

- медико-біологічна оцінка кулінарних продуктів для функціонального харчування.

Основним принципом створення функціональних продуктів можна вважати зміцнення здоров'я людини шляхом впливу на визначені фізіологічні реакції організму ${ }^{23}$.

Останніми роками на арену біодобавок активно виходять численні кріодобавки. Так, А.О. Пащенко (2016) запропонувала використовувати кріопорошок «Гарбуз» для промислового

19 Sadowska-Rociek, A., Mickowska B., Cieślik E. Assessment of nutrient content in selected dairy products for compliance with the nutrient content claims. Journal of Microbiology, Biotechnology and Food Sciences. 2013; 2(Special issue):1891-1897

${ }^{20}$ Савченкова Л.В., Немятих О.Д., Тернинко I.І., Рокотянська В.В., Акімова М.С., Бурцева О.М., Кулдиркаєва Є.В. Лікарські рослини як джерело створення нових лікарських засобів / Луганськ : СПД Рєзнік В.С., 2012. 64 с

21 Мазараки А.А. Технологія продуктів функціонального призначення. / А.А. Мазараки, М.І. Пересічний, М.Ф. Кравченко. Київ : Київ. нац. торг.-екон. універстет. 2012. $116 \mathrm{c.}$

${ }_{22}$ Сирохман I.В., Загородня В.М. Товарознавство продуктів функціонального призначення / навч. посібник для студентів ВНЗ. Київ, 2009. 544 с.

23 Грек О.В., Скорченко Т.А. Технологія комбінованих продуктів на молочній основі : Підручник / НУХТ. Київ, 2012. 362 с. 
виробництва солодких та солених сиркових мас лікувальнопрофілактичного напряму.

Н.І. Тицейко (2016) розробила для промислового виробництва рецептури солених сиркових мас лікувально-профілактичного напряму із кріопорошками «Морська капуста» та «Брокколі». ${ }^{24}$

А. Ільїнська і співавтори (2017) рекомендують використання кріопорошків «Гарбуз», «Амарант», «Брокколі» та «Морська капуста» як біодобавок до «молочної основи» кисломолочного сиру, а також плавленого сиру «Домашній». О. Грабарчук, А. Ільїнська, В. Кобернюк (2018) пропонують використання кріопорошків у технології молочних продуктів лікувально-профілактичного напряму $^{25}$.

Ю. Лісовська, О. Пунейко (2018) розробили промислові рецептури молочних продуктів лікувально-профілактичного напряму з кріопорошком із морепродуктів ${ }^{26}$.

I такі дослідження активно продовжуються та розширюються досі.

Враховуючи вищенаведене, використання кріопорошків, в тому числі і пропонованого нами кріопорошку «Буряк», як додаткових рецептурних складників в технології солодких і солених плавлених сирів є цікавим, оправданим, корисним для науки, 3 подальшим якнайшвидшим впровадженням у виробничий цикл молокопереробних підприємств України.

Традиційно буряк має широкий спектр застосування в народній медицині, завдяки своїм корисним і цілющим властивостям. Корисні властивості буряка зумовлені наявністю в коренеплодах різних вітамінів, бетаїну, мінеральних речовин, біофлавоноїдів. Вживається як загальнозміцнюючий продукт, що покращує травлення і обмін речовин. Кобальт, що міститься в буряку, допомагає організму синтезувати вітамін В12, а йод захищає щитовидну залозу, зберігає

${ }^{24}$ Гачак, Ю.Р. Застосування рослинної біодобавки в технології плавлених сирів / Ю.Р. Гачак,О.Р. Михайлицька. Збірник матеріалів наукової конференції «Оздоровчі харчові продукти та дієтичні добавки: технології, якість та безпека». Київ : НУХТ, 2014. С. 31-32.

25 Ільїнська А. Беницька А., Пристанський Р. Кріопорошки в якості біодобавок у молочних продуктах ЛПН. Актуальні задачі сучасних технологій 6 збірник тез доповідей н. т. конференції молодих учених та студентів. Тернопіль, 2017. С. 174-175.

26 Лісовська Ю., Пунейко О. Розробка рецептур молочних продуктів ЛПН із кріопорошком із морепродуктів. Дні студентської науки у ЛНУВМ та БТ імені С.3 Гжицького: Матеріали студентської конференції. Львів, 2018. С. 110-111. 
пам'ять і працездатність. Дуже важливою речовиною, що містяться в буряку, $є$ бетаїн, біологічно активна речовина, необхідна для повного засвоєння білка. Бетаїн настільки активний, що дозволяє засвоювати білки, що містяться в м'ясі, майже на 100\%. Добре поліпшується робота печінки під дією бетаїну, що входить до складу буряків. Буряк містить значну кількість мінеральних сполук. Зокрема, всі біометали натрій, калій, магній, кальцій, марганець, залізо, кобальт, мідь, цинк, молібден. Буряк містить численні вітаміни (з розрахунку на 100 грамів продукту): Вітамін А - 0.01 мг, Вітамін В1 - 0.02 мг, Вітамін В2 0.04 мг, Вітамін В3 - 0.1 мг, Вітамін В6 - 0.07 мг, Вітамін В9 13.0 мкг, Вітамін C - 10.0 мг, Вітамін Е - 0.1 мг, Вітамін РP -0.2 мг $^{27}$.

Метою роботи була розробка нової технології солодких та солених сиркових мас з використанням кріопорошку «Буряк».

Для досягнення поставленої мети необхідно було вирішити ряд завдань:

- обгрунтувати доцільність використання кріопорошку «Буряк» у технології соленого і солодкого плавленого сиру;

- дослідити органолептичні показники солодких та солених плавлених сирів із використанням кріопорошку «Буряк»;

- дослідити основні фізико-хімічні показники солодких та солених плавлених сирів із кріопорошком «Буряк».

\section{2. Матеріал та методи досліджень}

Планом наукових досліджень були передбачені експерименти в умовах наукової лабораторії кафедри технології молока і молочних продуктів Львівського національного університету ветеринарної медицини та біотехнологій імені С.3. Гжицького та на виробництві.

Для досліджень використовували кріопорошок «Буряк». Дози пропонованої фітодобавки розроблялись на основі рекомендованих добових норм споживання плавленого сиру для різних вікових груп, лікувально-профілактичних доз біодобавки. Сам кріопорошок вносили безпосередньо у сирну суміш перед плавленням.

В якості молочної прототипів нами використано:

1. Для сиру соленого плавленого із кріопорошком «Буряк»рецептуру традиційного плавленого сиру «Російський».

2. Для сиру солодкого плавленого із кріопорошком «Буряк» рецептуру солодкого плавленого сиру «Фруктовий».

27 Мусульманова М.M. Комбинированные молочно-растительные продукты. Молочная промышленность. 2006. № 5. С. 72-73. 
Першим етапом наукових досліджень було заплановано розробку рецептур нового плавленого сиру із кріопорошком «Буряк» на базі вказаних прототипів.

Компоненти суміші для плавлення попередньо готувались згідно 3 вимогами технологічних інструкцій під час виробництва плавлених сирів. Плавлення суміші здійснювали при температурі 80-82 ${ }^{\circ}$ C. Вибір та пошук доз складників проводився:

- за збереження максимально наближених нормативних характеристик плавленого сиру;

-забезпечення смакових характеристик плавленого сиру iз додаванням пропонованої біодобавки.

Дослідження проб готової продукції здійснювали відповідно до ГОСТ 26809-86 «Молоко і молочні продукти. Правила приймання. Методи відбору і підготовка проб аналізу» та ДСТУ ISO 707-2002 «Молоко і молочні продукти. Настанови з відбирання проб»; ДСТУ ISO 5538:2004 «Молоко і молочні продукти. Відбирання проб. Контроль за якісними показниками» ${ }^{28}$.

\section{3. Результати досліджень та їх обговорення}

\section{1. Розробка рецептур плавленого сиру: (соленого та солодкого) із використанням кріопорошку «Буряк»}

\subsection{1. Сир плавлений солений із кріопорошком «Буряк»}

Сир, вибраний нами як прототип - плавлений сир «Російський», належить до плавлених сирів «Сири плавлені скибкові». Плавлені сири цієї групи характеризуються певним складом жиру у сухій речовині, вмістом вологи, кухонної солі, мають певну величину $\mathrm{pH} \mathrm{\textrm {i }}$ свої органолептичні характеристики, що відрізняють їх $\mathrm{y}$ технологічній та товарознавчій характеристиці цього виду продукції.

Під час підбору рецептурних складників для соленого плавленого сиру за основу нами було вибрано базову рецептуру плавленого сиру «Російський».

У результаті проведених досліджень та численних дегустацій було відібрано оптимальну, на наш погляд, рецептуру (табл. 1), де

${ }^{28}$ Samilyk M. Improving the technology of soft sour milk cheese by increasing biological value. Scientific Messenger of Lviv National University of Veterinary Medicine and Biotechnologies. 2017. Vol. 19, № 80. P. 33-37. 
незначну частину самого сухого знежиреного молока (30,6 проти 33,6 на 1000 кг готового продукту) у дослідному зразку було замінено на пропонований кріопорошок «Буряк». Кількість внесення пропонованого кріопорошку «Буряк» визначили органолептичні властивості дослідних зразків, їх відповідність традиційній продукції - соленому плавленому сиру - «прототипу».

Таблиця 1

Рекомендовані рецептури плавленого сиру «Російський» та сир солений з кріопорошком «Буряк»

\begin{tabular}{|c|c|c|c|}
\hline \multirow{2}{*}{$\mathfrak{*} №$} & Сировина & \multicolumn{2}{|c|}{ Сир плавлений } \\
\cline { 3 - 4 } & «Російський» & $\begin{array}{c}\text { Із кріопорошком } \\
\text { «Буряк» }\end{array}$ \\
\hline 1 & Сир «Російський» & 380,0 & 380,0 \\
\hline 2 & Сир «Голландський» & 385,0 & 385,0 \\
\hline 3 & $\begin{array}{c}\text { Молоко коров'яче сухе } \\
\text { знежирене (мч СР 96\%) }\end{array}$ & 33,6 & 29,6 \\
\hline 4 & $\begin{array}{c}\text { Суміш триполіфосфат } \\
\text { натрію (мч СР 20\% })\end{array}$ & 102,0 & 102,0 \\
\hline 5 & $\begin{array}{c}\text { Масло «Селянське» } \\
\text { (мч СР 75\%, мчж 72,5\% })\end{array}$ & 33,4 & 33,4 \\
\hline 6 & Вода питна & 102,8 & 102,8 \\
\hline 7 & Кріопорошок «Буряк» & - & 4,0 \\
\hline 8 & Всього & 1020 & 1020 \\
\hline 9 & Вихід & 1000 & 1000 \\
\hline
\end{tabular}

У розробленому нами та пропонованому виробництву соленому плавленому сирі (табл. 1.) складники запропоновано у таких кількостях (із розрахунку на 1000 кг готового продукту): сир сичужний дрібний «Голландський» - 385,0 кг; сир сичужний дрібний «Російський» - 380,0 кг молоко коров'яче сухе знежирене 3 МЧ СР 96\% - 29,6 кг; масло «Селянське» - 33,4 кг ; натрій фосфорнокислий $(20 \%$ р-н) - 102,8 кг; вода питна - 102,8 кг та кріопорошок «Буряк» - 4,0 кг.

Як засвідчили результати дегустаційної оцінки численних дослідних зразків, саме ця рецептура i отримала найкращу органолептичну оцінку.

\subsection{2. Сир плавлений солодкий із кріопорошком «Буряк»}

Сир, вибраний нами як прототип плавленого сиру належить до плавлених сирів «Сири плавлені солодкі». Плавлені сири цієї групи 
характеризуються також певним складом жиру у сухій речовині, вмістом вологи, кухонної солі, мають певну величину $\mathrm{pH}$ і свої органолептичні характеристики, що відрізняють їх у технологічній та товарознавчій характеристиці даного виду продукції.

Під час підбору рецептурних складників для солодкого плавленого сиру за основу нами було вибрано базову рецептуру плавленого сиру «Фруктовий», у склад якого, поряд 3 сичужним сиром «Голландський», нормативними вимогами передбачено додавання сухого знежиреного молока, масла селянського, соліплавителя (триполіфосфату натрію), кисломолочного сиру нежирного та напівжирного, фруктової есенції та води питної.

У результаті проведених досліджень та численних дегустацій було відібрано оптимальну, на наш погляд, рецептуру (табл. 2). Незначну частину самого сухого знежиреного молока в процесі наукового пошуку у дослідному зразку було замінено на пропонований кріопорошок «Буряк». Кількість внесення кріопорошку визначили органолептичні властивості дослідних зразків, їх відповідність традиційній продукції - солодкому плавленому сиру - прототипу «Фруктовий».

Таблиця 2

\section{Рекомендовані рецептури плавленого сиру «Фруктовий»} та із кріопорошком «Буряк»

\begin{tabular}{|c|c|c|c|}
\hline \multirow[b]{2}{*}{ № } & \multirow{2}{*}{$\begin{array}{c}\text { Сировина під час } \\
\text { виготовлення плавленого } \\
\text { сиру традиційного } \\
\text { та із кріопорошком «Буряк» }\end{array}$} & \multicolumn{2}{|c|}{ Сир плавлений } \\
\hline & & $\begin{array}{l}\text { «Фруктовий» } \\
\text { традиційний }\end{array}$ & $\begin{array}{c}\text { iз } \\
\text { кріопорошком } \\
\text { «Буряк» }\end{array}$ \\
\hline 1. & $\begin{array}{c}\text { Сир сичужний дрібний } \\
\text { «Голландський» }\end{array}$ & 82,4 & 82,4 \\
\hline 2. & Сир кисломолочний нежирний & 114,5 & 114,5 \\
\hline 3. & $\begin{array}{c}\text { Сир кисломолочний } \\
\text { напівжирний } 9 \%\end{array}$ & 144,2 & 144,2 \\
\hline 4. & $\begin{array}{c}\text { Молоко коров'яче сухе } \\
\text { знежирене з МЧ СР } 96 \%\end{array}$ & 61,8 & 58,8 \\
\hline 5. & Масло вершкове & 213,5 & 213,5 \\
\hline 6. & Есенція фруктова & 1,0 & - \\
\hline 7. & $\begin{array}{c}\text { Натрій фосфорнокислий } \\
(20 \% \text { p-н) }\end{array}$ & 51,9 & 51,9 \\
\hline 8. & Цукор пісок & 257,5 & 257,5 \\
\hline 8. & Вода питна & 103,2 & 103,2 \\
\hline 9. & Кріопорошок «Буряк» & - & 3,0 \\
\hline 10. & Всього & 1000 & 1000 \\
\hline
\end{tabular}


У результаті наших експериментів ми також намагалися максимально зберегти нормативні органолептичні характеристики та технологічні параметри молочної основи (плавленого сиру) та кріопорошку, знайти їх оптимальне співвідношення.

Під час підбору рецептурних складників для солодкого плавленого сиру відповідно сир «Фруктовий», у склад рецептури якого, поряд із сичужним сиром «Голландський», нормативними вимогами передбачено додавання сухого знежиреного молока, масла селянського, кисломолочного нежирного та напівжирного кисломолочного сирів, есенції фруктової, цукру, солі-плавителя (триполіфосфату натрію) та води питної.

Як основу нами вибрано відповідну рецептуру сиру «Фруктовий». Робота дегустаційної комісії дозволила вибрати оптимальну. За рецептурним складом пропонований нами дослідний плавлений сир вирізнявся певними змінами не лише у кількісному складі, але й усуненням із рецептури солодкої есенції та заміни незначної кількості сухого знежиреного молока пропонованим кріопорошком «Буряк», яка суттєво не впливала на формування органолептики, близької до органолептики прототипу сиру плавленого «Фруктовий».

У запропонованому нами солодкому плавленому сирі складники запропоновано у таких кількостях (із розрахунку на 1000 кг готового продукту): сир сичужний дрібний «Голландський» 82,4 кг; сир кисломолочний нежирний - 114,5 кг; сир кисломолочний напівжирний 9\% - 144,2 кг; молоко коров'яче сухе знежирене з МЧ СР 96\% - 58,8 кг; масло вершкове - 213,5 кг; натрій фосфорнокислий (20\% р-н) - 51,9 кг; цукор пісок - 257,5 кг; вода питна - 103,2 кг та кріопорошок «Буряк» - 3,0 кг (табл. 2).

Як засвідчили результати дегустаційної оцінки численних дослідних зразків, саме ця рецептура i отримала найкращу органолептичну оцінку.

\section{2. Технологічні характеристики та бальна оцінка плавлених сирів із використанням кріопорошку «Буряк»}

Згідно з нормативними вимогами щодо нової чи модифікованої продукції іï оцінка та визначення технологічних якостей сиру $\epsilon$ основним фактором для встановлення рівня цін для кожного продукту, дозволяє виявляти, а потім і ліквідувати можливі недоліки під час їх виготовлення. 
Як відомо, повноцінна оцінка технологічної якості сиру забезпечується за рахунок використання прямих чи непрямих методів вимірювань за допомогою приладів. Як прямі методи можуть бути використані вимірювання харчових консистенцій чи аналіз складових елементів, що відповідають за формування аромату сиру. Під час проведення непрямих вимірювань дослідники звертаються до хімічних i ферментативних аспектів, використовуючи мікроскопію і різні фізичні методи досліджень.

Серед органолептичних характеристик особливе значення в оцінці якості продукції мають запах, смак, консистенція, колір сирних виробів. Важливе значення мають також товарний вигляд продукції - ступінь наповнення упаковки, щільність і правильність фасування, іiі зовнішній вигляд.

Додавання до рецептури кріопорошку «Буряк» привело певної зміни органолептики дослідних зразків пропонованих соленого та солодкого плавленого сиру (табл. 3,4 ).

Таблиця 3

Органолептичні показники плавленого сиру «Російський» та соленого $з$ кріопорошком «Буряк»

\begin{tabular}{|c|c|c|c|}
\hline № & $\begin{array}{c}\text { Назва } \\
\text { показника }\end{array}$ & $\begin{array}{l}\text { Традиційний } \\
\text { плавлений } \\
\text { «Російський» }\end{array}$ & $\begin{array}{c}\text { Плавлений сир із } \\
\text { кріопорошком «Буряк» }\end{array}$ \\
\hline 1 & Смак і запах & $\begin{array}{c}\text { Виражений сирний } \\
\text { кислуватий }\end{array}$ & $\begin{array}{c}\text { Ситний смак, злегка солений, } \\
\text { сторонніх запаху і смаку не } \\
\text { виявлено }\end{array}$ \\
\hline 2 & Консистенція & $\begin{array}{c}\text { Пластична, злегка } \\
\text { пружна }\end{array}$ & $\begin{array}{c}\text { В міру щільна, злегка пружна, } \\
\text { наявний зовнішній блиск }\end{array}$ \\
\hline 3 & Колір тіста & $\begin{array}{c}\text { Від світло-жовтого до } \\
\text { жовтого } \\
\end{array}$ & $\begin{array}{c}\text { Рожевий, однорідний } \\
\text { по всій масі }\end{array}$ \\
\hline 4 & $\begin{array}{l}\text { Вид на } \\
\text { розрізі }\end{array}$ & $\begin{array}{c}\text { Відсутність рисунку, } \\
\text { допускається } \\
\text { наявність пустот } \\
\end{array}$ & Відсутність рисунку та пустот \\
\hline 5 & $\begin{array}{l}\text { Зовнішній } \\
\text { вигляд }\end{array}$ & $\begin{array}{l}\text { Поверхня чиста, не } \\
\text { підсохла, не } \\
\text { запліснявіла }\end{array}$ & $\begin{array}{c}\text { Поверхня чиста, не підсохла, } \\
\text { блискуча }\end{array}$ \\
\hline
\end{tabular}

Аналіз органолептичних ознак соленого плавленого сиру iз кріопорошком «Буряк», наведених у таблиці 3, вказує, що дослідні зразки сиру зберігають в міру щільну, злегка пружну консистенцію, наявний зовнішній блиск, мають характерний оригінальний смак $\mathrm{i}$ запах (ситний смак, злегка солений). Дослідні зразки зовні мали 94 
скоринку, на розрізі - суцільну мазеподібну масу. Колір дослідних зразків був рожевий, однорідний по всій масі.

Зовнішня поверхня дослідних зразків (кружки, бруски) чиста, не підсохла, блискуча.

У наступній серії експериментів було проведено дослідження органолептики солодкого плавленого сиру із кріопорошком «Буряк».

Таблиця 4

Органолептичні показники солодкого плавленого сиру «Фруктовий» та солодкого з кріопорошком «Буряк»

\begin{tabular}{|c|c|c|c|}
\hline № & $\begin{array}{c}\text { Назва } \\
\text { показника }\end{array}$ & $\begin{array}{c}\text { Традиційний плавлений } \\
\text { «Фруктовий» }\end{array}$ & $\begin{array}{c}\text { Плавлений сир із } \\
\text { кріопорошком «Буряк» }\end{array}$ \\
\hline 1 & Смак і запах & $\begin{array}{c}\text { Солодкий, злегка } \\
\text { кислуватий із вираженим } \\
\text { смаком і ароматом } \\
\text { лимону, апельсину }\end{array}$ & $\begin{array}{c}\text { Солодкий, сторонніх } \\
\text { смаку та запаху не } \\
\text { виявлено }\end{array}$ \\
\hline 2 & Консистенція & Ніжна, пластична & $\begin{array}{c}\text { Ніжна, пластична } \\
\text { однорідна; зовні наявний } \\
\text { блиск }\end{array}$ \\
\hline 3 & Колір тіста & $\begin{array}{c}\text { Зумовлений внесеним } \\
\text { смаковим наповнювачем }\end{array}$ & $\begin{array}{c}\text { Яскраво червоний, } \\
\text { однорідний по всій масі }\end{array}$ \\
\hline 4 & $\begin{array}{c}\text { Вид на розрізі } \\
\text { дідсутність рисунку, } \\
\text { допускаст наявність } \\
\text { пустот }\end{array}$ & $\begin{array}{c}\text { Суцільна пружна маса, } \\
\text { зверху наявна скоринка }\end{array}$ \\
\hline 5 & $\begin{array}{c}\text { Зовнішній } \\
\text { вигляд }\end{array}$ & $\begin{array}{c}\text { Поверхня чиста, не } \\
\text { підсохла, не запліснявіла }\end{array}$ & $\begin{array}{c}\text { Поверхня чиста, не } \\
\text { підсохла, блискуча }\end{array}$ \\
\hline
\end{tabular}

Аналіз органолептичних ознак солодкого плавленого сиру iз кріопорошком «Буряк», наведених у таблиці 4, вказує, що дослідні зразки сиру зберігають ніжну, пластичну консистенцію, наявний зовнішній блиск, мають характерний оригінальний смак і запах (солодкий, приємний, сторонніх запаху і смаку не виявлено). Дослідні зразки зовні мали тоненьку кірочку, на розрізі - суцільну мазеподібну масу. Колір дослідних зразків був яскраво червоний, однорідний по всій масі. Зовнішня поверхня дослідних зразків (кружки, бруски) чиста, не підсохла, блискуча.

У подальшому досліджували фізико-хімічні властивості традиційних прототипів сирів із додаванням біодобавки кріопорошку «Буряк».

Як видно з таблиці 5, дослідні зразки сиру плавленого соленого фасувались у традиційні форми (батончики) та у форми кружків. 
Маса дослідних зразків сиру була в межах 100 г. Так, масова частка жиру у сухій речовині складає у продукті - 45,6\% (у традиційному 45\%). Представлені дослідні зразки сиру характеризувались зміненими величинами масової частки вологи $-45,4 \%$ проти 45,0; та солі - 2,4 проти $2,0 \%$ у контролі; а $\mathrm{pH}$ дослідних зразків плавленого сиру із кріопорошком відповідно складав 5,6, що відповідає нормативним вимогам.

Таблиця 5

Фізико-хімічні показники плавленого сиру «Російський» та соленого з кріопорошком «Буряк»

\begin{tabular}{|c|c|c|c|c|c|c|}
\hline \multirow[b]{2}{*}{ № } & \multirow[b]{2}{*}{ Назва сиру } & \multicolumn{3}{|c|}{ Вміст, \% } & \multirow[b]{2}{*}{$\begin{array}{l}\text { pH } \\
\text { сиру }\end{array}$} & \multirow[b]{2}{*}{$\begin{array}{r}\text { Форма } \\
\text { i мaсa }(\Gamma)\end{array}$} \\
\hline & & $\begin{array}{c}\text { жиру в } \\
\text { сухій } \\
\text { речовині }\end{array}$ & $\begin{array}{c}\begin{array}{c}\text { вологи, } \\
\text { не } \\
\text { менше }\end{array} \\
\end{array}$ & $\begin{array}{c}\text { солі, } \\
\text { не } \\
\text { менше }\end{array}$ & & \\
\hline 1 & $\begin{array}{c}\text { Нормативні } \\
\text { вимоги, щодо } \\
\text { плавленого сиру } \\
\text { «Російський» }\end{array}$ & 45 & 50 & 2,0 & $5,6-5,7$ & $\begin{array}{c}\text { батон } \\
\text { масою } \\
100 г\end{array}$ \\
\hline 2 & $\begin{array}{c}\text { Сир плавлений } 3 \\
\text { кріопорошком } \\
\text { «Буряк» }\end{array}$ & 45,6 & 45,4 & 2,4 & 5,6 & $\begin{array}{c}\text { батон } \\
\text { масою } \\
100 \text { г } \\
\text { кружки } \\
\text { масою } \\
100 \text { г } \\
\end{array}$ \\
\hline
\end{tabular}

Результати досліджень фізико-хімічних показників плавленого солодкого сиру наведені у таблиці 6.

Як видно, дослідні зразки сиру також фасувались як у традиційні форми (батончики), так і у форми кружків. Маса дослідних зразків сиру була в межах 100 г. В той же час масова частка жиру у сухій речовині складає у продукті - 30,4\% (у традиційному - 30\%). Представлені дослідні зразки сиру характеризувались зміненими величинами масової частки вологи - 27,6\% та сахарози $-27,6 \%$ а $\mathrm{pH}$ дослідних зразків плавленого сиру із кріопорошком відповідно складав 5,6, що загалом відповідає нормативним вимогам.

Якими не були б фізико-хімічні характеристики нових чи модифікованих продуктів для потенційного споживача вкрай важливу роль відіграють візуальні та смакові характеристики продукції.

У зв'язку із цим проведення дегустаційної оцінки харчових продуктів, в тому числі і нових молочних, є необхідним. 
Таблиця 6

Фізико-хімічні показники солодкого плавленого сиру «Фруктовий» та солодкого з кріопорошком «Буряк»

\begin{tabular}{|c|c|c|c|c|c|c|}
\hline \multirow[b]{2}{*}{ № } & \multirow[b]{2}{*}{ Назва сиру } & \multicolumn{3}{|c|}{ Вміст, \% } & \multirow[b]{2}{*}{$\begin{array}{l}\text { pH } \\
\text { сиру }\end{array}$} & \multirow[b]{2}{*}{$\begin{array}{c}\text { Форма } \\
\text { i мaca } \\
(\text { г) }\end{array}$} \\
\hline & & $\begin{array}{c}\text { жиру в } \\
\text { сухій } \\
\text { речовині }\end{array}$ & $\begin{array}{c}\text { вологи, } \\
\text { не } \\
\text { менше }\end{array}$ & $\begin{array}{c}\text { caxaposи, } \\
\text { не } \\
\text { менше }\end{array}$ & & \\
\hline 1 & $\begin{array}{c}\text { Сир плавлений } \\
\text { традиційний } \\
\text { солодкий } \\
\text { «Фруктовий» }\end{array}$ & 30,0 & 39 & 25 & 5,7 & $\begin{array}{c}\text { батон } \\
\text { масою } \\
100 \text { г }\end{array}$ \\
\hline 2 & $\begin{array}{c}\text { Сир плавлений із } \\
\text { кріопорошком } \\
\text { «Буряк» }\end{array}$ & 30,4 & 27,6 & 25,2 & 5,6 & $\begin{array}{c}\text { батон } \\
\text { масою } \\
100 \text { г } \\
\text { кружки } \\
\text { масою } \\
100 \text { г }\end{array}$ \\
\hline
\end{tabular}

Таблиця 7

Результати дегустаційної оцінки соленого плавленого сиру «Російський» та соленого 3 кріопорошком «Буряк»

\begin{tabular}{|c|c|c|c|c|c|c|}
\hline \multirow{3}{*}{ № } & \multirow{3}{*}{$\begin{array}{c}\text { Назва } \\
\text { показника } \\
\text { плавленого } \\
\text { сиру }\end{array}$} & \multirow{3}{*}{$\begin{array}{c}\text { кількість } \\
\text { балів }\end{array}$} & \multicolumn{4}{|c|}{ Результати дегустації } \\
\hline & & & \multicolumn{2}{|c|}{$\begin{array}{c}\text { традиційного } \\
\text { солодкого } \\
\text { плавленого сиру } \\
\text { «Російський» } \\
\end{array}$} & \multicolumn{2}{|c|}{$\begin{array}{c}\text { Плавленого сиру } \\
\text { кріопорошком } \\
\text { «Буряк» }\end{array}$} \\
\hline & & & 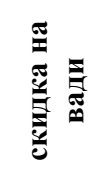 & 气ึ & 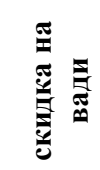 & قُ \\
\hline 1 & Смак і запах & 15 & 1 & 14 & 1 & 14 \\
\hline 2 & Консистенція & 9 & 1 & 8 & 0 & 9 \\
\hline 3 & Колір тіста & 2 & 0 & 2 & 1 & 1 \\
\hline 4 & $\begin{array}{l}\text { Вид на } \\
\text { розрізі }\end{array}$ & 2 & 0 & 2 & 0 & 2 \\
\hline 5 & $\begin{array}{l}\text { Зовнішній } \\
\text { вид }\end{array}$ & 2 & 0 & 1 & 1 & 2 \\
\hline 6 & Всього & 30 & 2 & 27 & 3 & 28 \\
\hline
\end{tabular}


Таблиця 8

Результати дегустаційної оцінки плавленого сиру «Фруктовий»

та солодкого з кріопорошком «Буряк»

\begin{tabular}{|c|c|c|c|c|c|c|}
\hline \multirow[b]{3}{*}{ № } & \multirow{3}{*}{$\begin{array}{c}\text { Назва } \\
\text { показника } \\
\text { плавленого } \\
\text { сиру }\end{array}$} & \multirow{3}{*}{$\begin{array}{c}\text { Кількість } \\
\text { балів }\end{array}$} & \multicolumn{4}{|c|}{ Результати дегустації } \\
\hline & & & \multicolumn{2}{|c|}{$\begin{array}{l}\text { плавленого сиру } \\
\text { «Фруктовий» }\end{array}$} & \multicolumn{2}{|c|}{$\begin{array}{c}\text { сир із } \\
\text { кріопорошком } \\
\text { «Буряк» } \\
\end{array}$} \\
\hline & & & 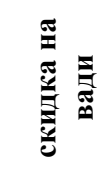 & 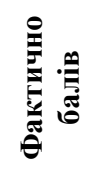 & 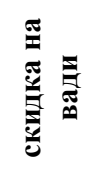 & 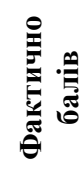 \\
\hline 1 & Смак і запах & 15 & 1 & 14 & 1 & 14 \\
\hline 2 & Консистенція & 9 & 0 & 9 & 0 & 9 \\
\hline 3 & Колір тіста & 2 & 0 & 2 & 0 & 2 \\
\hline 4 & $\begin{array}{l}\text { Вид на } \\
\text { розрізі }\end{array}$ & 2 & 0 & 2 & 0 & 2 \\
\hline 5 & $\begin{array}{l}\text { Зовнішній } \\
\text { вид }\end{array}$ & 2 & 0 & 1 & 1 & 1 \\
\hline 6 & Всього & 30 & 1 & 29 & 2 & 28 \\
\hline
\end{tabular}

Проведена нами дегустаційна оцінка зразків плавленого сиру солодкого та соленого різної жирності із додаванням кріопорошку «Буряк» засвідчила відповідно по 28 балів для кожного з 30 балів можливих, що свідчить про нормативну відповідність товарознавчих характеристик (табл. 7 та 8 ).

\section{3. Оцінка біологічної цінності плавлених сирів із використанням кріопорошку «Буряк»}

Оцінка біологічної цінності нових чи модифікованих харчових продуктів оцінюється за вмістом біологічно активних речовин, в тому числі вітамінів.

Додавання до складу плавлених сирів кріопорошку «Буряк» не лише надає продукції належного товарного вигляду та привабливого кольору, але й підвищує у них вміст вітамінів (табл. 9, 10). 
Таблиця 9

Вміст вітамінів у плавленому сирі «Російський» та соленому з кріопорошком «Буряк»

\begin{tabular}{|c|c|c|c|c|c|c|}
\hline \multirow{2}{*}{$\begin{array}{c}\text { № } \\
\text { п/п }\end{array}$} & Назва продукту & \multicolumn{4}{|c|}{ Вміст вітамінів, мг/100г продукту } \\
\cline { 3 - 7 } & B-каротин & B1 & B2 & PP & С \\
\hline 1. & $\begin{array}{c}\text { Сири плавлені } \\
\text { (нормативні вимоги) }\end{array}$ & 0,08 & 0,02 & 0,39 & 0,15 & 1,2 \\
\hline 2. & Сир плавлений «Російський» & 0,09 & 0,02 & 0,36 & 0,14 & 1,3 \\
\hline 3. & $\begin{array}{c}\text { Сир плавлений } 3 \\
\text { кріопорошком «Буряк» }\end{array}$ & 0,14 & 0,04 & 0,44 & 0,18 & 1,9 \\
\hline
\end{tabular}

Таблиця 10

Вміст вітамінів у плавленому сирі «Фруктовий»

та солодкому $з$ кріопорошком «Буряк»

\begin{tabular}{|c|c|c|c|c|c|c|}
\hline \multirow{2}{*}{$\begin{array}{c}\text { № } \\
\text { п/п }\end{array}$} & Назва продукту & \multicolumn{4}{|c|}{ Вміст вітамінів, мг/100г продукту } \\
\cline { 3 - 8 } & B-каротин & $\mathbf{B 1}$ & $\mathbf{B 2}$ & $\mathbf{P P}$ & $\mathbf{C}$ \\
\hline 1. & $\begin{array}{c}\text { Сири плавлені } \\
\text { (нормативні вимоги) }\end{array}$ & 0,08 & 0,02 & 0,39 & 0,15 & 1,2 \\
\hline 2. & $\begin{array}{c}\text { Сир плавлений традиційний } \\
\text { солодкий «Фруктовий» }\end{array}$ & 0,10 & 0,03 & 0,41 & 0,16 & 1,4 \\
\hline 3. & $\begin{array}{c}\text { Сир плавлений солодкий із } \\
\text { кріопорошком «Буряк» }\end{array}$ & 0,12 & 0,04 & 0,42 & 0,16 & 1,5 \\
\hline
\end{tabular}

У вищенаведених таблицях наведено вітамінний склад у плавлених сирах традиційного виробництва та прототипах iз зміненою рецептурою шляхом збагачення кріопорошком «Буряк».

Як видно із цифрового матеріалу, дослідні зразки плавленого сиру із кріопорошком мали підвищені порівняно із традиційними сирами величини нормативно передбачених вітамінів. Аналіз табличних даних засвідчив більший приріст нормативнопередбачених вітамінів у соленому плавленому сирі iз кріопорошком порівняно із плавленим солодким сиром. Це, на нашу думку, пов'язано із більшою рецептурною кількістю самого кріопорошку. Слід зазначити, що кріотехнологія забезпечує зберігання природних вітамінів у кріопорошках.

\section{4. Показники безпеки плавлених сирів із використанням кріопорошку «Буряк»}

Згідно 3 вимогами нормативних вимог до показників безпеки харчових продуктів обов'язково відносять дослідження вмісту токсичних елементів та мікробіологічні дослідження. У зв'язку 3 цим нами були проведені дослідження вмісту важких металів у всіх зразках плавленого сиру солодкого та соленого. 
У таблицях 11 та 12 наведені результати досліджень вмісту важких металів у дослідних зразках плавленого сиру традиційного прототипу та відповідного із кріопорошком «Буряк».

Таблиця 11

Вміст важких металів у зразках плавленого сиру «Російський» та соленого 3 кріопорошком «Буряк»

\begin{tabular}{|c|c|c|c|c|c|c|c|c|}
\hline \multirow[b]{2}{*}{ № } & \multirow[b]{2}{*}{$\begin{array}{c}\text { Досліджуван } \\
\text { і зразки }\end{array}$} & \multicolumn{7}{|c|}{ Вміст важких металів у плавлених сирах (мг/кг) } \\
\hline & & 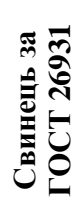 & 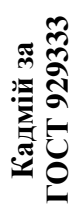 & 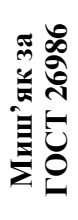 & 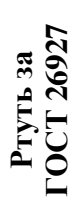 & 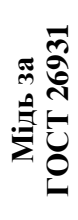 & 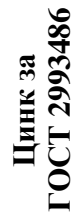 & 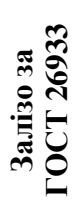 \\
\hline 1. & $\begin{array}{c}\text { Нормативні } \\
\text { вимоги по } \\
\text { плавлених } \\
\text { сирах } \\
\end{array}$ & 0,3 & 0,2 & 0,2 & 0,02 & 4,0 & 5,0 & - \\
\hline 2. & $\begin{array}{c}\text { Сир } \\
\text { плавлений } \\
\text { традиційний }\end{array}$ & 0,24 & 0,07 & - & - & 2,7 & 3,8 & - \\
\hline 3. & $\begin{array}{c}\text { Сир } \\
\text { плавлений із } \\
\text { кріопорошко } \\
\text { м «Буряк» }\end{array}$ & 0,22 & 0,06 & - & - & 2,7 & 3,8 & - \\
\hline
\end{tabular}

Таблиця 12

Вміст важких металів у зразках солодкого плавленого сиру «Фруктовий» та 3 кріопорошком «Буряк»

\begin{tabular}{|c|c|c|c|c|c|c|c|c|}
\hline \multirow[b]{2}{*}{ № } & \multirow[b]{2}{*}{$\begin{array}{c}\text { Досліджувані } \\
\text { зразки }\end{array}$} & \multicolumn{7}{|c|}{ Вміст важких металів у плавлених сирах (мг/кг) } \\
\hline & & 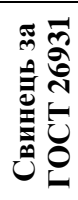 & 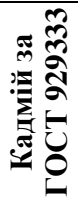 & 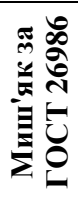 & 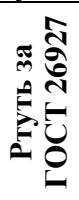 & 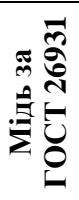 & 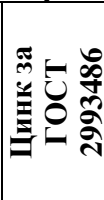 & 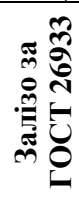 \\
\hline 1. & $\begin{array}{c}\text { Нормативні } \\
\text { вимоги по } \\
\text { плавлених сирах }\end{array}$ & 0,3 & 0,2 & 0,2 & 0,02 & 4,0 & 5,0 & - \\
\hline 2. & $\begin{array}{c}\text { Сир плавлений } \\
\text { традиційний } \\
\text { солодкий } \\
\text { «Фруктовий» }\end{array}$ & 0,20 & 0,05 & - & - & 2,7 & 3,6 & - \\
\hline 3. & $\begin{array}{c}\text { Сир плавлений із } \\
\text { кріопорошком } \\
\text { «Буряк» }\end{array}$ & 0,18 & 0,04 & - & - & 2,4 & 3,6 & - \\
\hline
\end{tabular}


Аналіз цифрового матеріалу показав, що у всіх дослідних зразках сиру плавленого як традиційного виробництва, так і аналогічних із кріопорошком «Буряк» концентрація таких важких металів, як свинець, кадмій, миш'як та ртуть, була на 2-3 порядки нижче від гранично допустимих величин. У той же час виявлена аналогічна тенденція щодо білыш високих кількостей мінеральних елементів у солених зразках плавленого сиру порівняно із солодким плавленим сиром із кріопорошком, де кількість останнього у рецептурі є дещо меншою.

Не менш важливими показниками безпеки харчових продуктів $\epsilon$ мікробіологічний контроль готової продукції. В Україні для організації та проведення мікробіологічного контролю керуються настановами, викладеними в нормативній документації на сировину та готову продукцію, санітарними правилами, інструкціями 3 миття та дезінфекції обладнання, а також інструкцією з мікробіологічного контролю виробництва на підприємствах молочної промисловості.

У виробництві плавлених сирів використовуються функціонально необхідні інгредієнти (ферментні препарати, закваски або заквашувальні препарати, солі-плавителі, сіль, цукор тощо); харчові добавки (загущувачі, стабілізатори, емульгатори, ароматизатори, барвники, консерванти тощо), наповнювачі (фрукти, овочі, спеції, зелень, горіхи тощо) та різні немолочні компоненти (рослинні жири, немолочні білки, м'ясні продукти тощо). Усі види та групи допоміжної сировини та компонентів повинні відповідати вимогам чинних нормативних документів на ці продукти.

Під час оцінки отриманих даних встановлено, що як традиційна продукція, так і дослідні зразки мали належні мікробіологічні показники, що позитивно характеризує як «культуру» технологічного процесу, так і самі продукти. В той же час шкідливої та небезпечної мікрофлори виявлено не було. Слід зазначити, що консервуюча дія інгредієнтів солі та цукру була дещо різною - сильнішою у разі застосування солі .

Таким чином, на основі проведених досліджень можна відзначити, що використання як сировини для виробництва плавленого сиру солодкого та соленого із використанням кріопорошку «Буряк» на основі плавленого сиру «Російський» та «Фруктовий» $\epsilon$ виправданим, а отримана продукція $є$ біологічно цінною, має належні товарознавчі характеристики, показники безпеки і розширює асортимент вітчизняної молочної продукції лікувально-профілактичного спрямування в Україні.

\section{ВИСНОВКИ}

1. Обгрунтовано доцільність використання кріопорошку «Буряк» в технології солодкого та соленого плавленого сиру. 
2. Запропонована біодобавка кріопорошок «Буряк» $\epsilon$ стандартною кріодобавкою, що не потребує суттєвого ускладнення технологічного процесу виготовлення плавленого соленого та солодкого сиру лікувально-профілактичного спрямування.

3. Розроблено виробничі рецептури соленого та солодкого плавленого сиру із використанням кріопорошку «Буряк».

4. Досліджено органолептичні, технологічні, біологічні властивості та показники безпеки дослідних зразків плавленого соленого та солодкого сиру із використанням кріопорошку «Буряк». Встановлено поліпшення якісних показників дослідних зразків порівняно 3 традиційними зразками. Плавлені сири за умов застосування кріопорошку «Буряк» мали приємний товарний вигляд.

5. Дослідні зразки плавленого сиру із кріопорошком мали підвищені порівняно із традиційними сирами величини нормативно передбачених вітамінів. Виявлені зміни у величинах вітамінів свідчать про підвищення біологічної цінності продукції та відповідності нормативних вимог.

\section{АНОТАЦІЯ}

Останніми роками перспективним $є$ збагачення молочних продуктів вітамінами та мінеральними речовинами шляхом додавання до них рослинних біодобавок у різних агрегатних станах. Саме тому метою роботи була розробка нової технології солодких та солених сиркових мас з використанням кріопорошку «Буряк». Дози пропонованої фітодобавки розроблялись на основі рекомендованих добових норм споживання плавленого сиру для різних вікових груп та лікувально-профілактичних доз біодобавки. Сам кріопорошок вносили безпосередньо у сирну суміш перед плавленням. На основі проведених досліджень обгрунтовано доцільність використання кріопорошку «Буряк» у технології солодкого та соленого плавленого сиру. Досліджено органолептичні, технологічні, біологічні властивості та показники безпеки дослідних зразків плавленого соленого та солодкого сиру із використанням кріопорошку «Буряк». Встановлено поліпшення якісних показників дослідних зразків порівняно 3 традиційними зразками. Плавлені сири за умов застосування кріопорошку «Буряк» мали приємний товарний вигляд, а також високий вміст вітамінів. Виявлені зміни у величинах вітамінів вказують на підвищення біологічної цінності продукції та відповідність нормативним вимогам. 


\section{ЛІТЕРАТУРА}

1. Bilyk, O. Substantiation of the method of protein extraction from sheep and cow whey for producing the cheese «Urda» / O. Bilyk, N. Slyvka, B. Gutyj, H. Dronyk, O. Sukhorska. Eastern-European Journal of Enterprise Technologies. Харків. 2017. В. 3. № 11(87). C. $18-22$.

2. Gutyj B. The elaboration of cheese masses of therapeutic and prophylactic direction with cryoadditive "Pumpkin" / B. Gutyj, Y. Hachak, J. Vavrysevych, V. Nagovska. "EUREKA: Life Sciences". 2017. № 1, 19-26.

3. Gutyj, B. The influence of cryopowder "Garbuz" on the technology of curds of different fat content / B. Gutyj, Y. Hachak, J. Vavrysevych, V. Nagovska. Eastern-European Journal of Enterprise Technologies. Харків. 2017. В. 2. № 10(86). С. 20-24

4. Ha, M. In-Depth Characterization of Sheep (Ovis aries) Milk Whey Proteome and Comparison with Cow (Bos taurus) / M. Ha, M. Sabherwal, E. Duncan, S. Stevens, P. Stockwell, M. McConnell, A. El-Din Bekhit, A. Carne. PLoS ONE. 2015. Vol. 10. Issues 10. e0139774 DOI 10.1371/journal.pone.0139774.

5. Horyuk Yu.V. Kukhtyn M.D., Perkiy Yu.B., Horyuk V.V., Semenyuk, V.I. Identification of Enterococcus isolated from raw milk and cottage cheese "home" production and study of their sensitivity to antibiotics. Scientific Messenger LNUVMBT named after S.Z. Gzhytskyj. 2016. Vol. 18, № 3(70). P. 44-48.

6. Kaminarides, S. Effect of added milk and cream on the physicochemical, rheological and volatile compounds of Greek whey cheeses / S. Kaminarides, K. Nestoratos, T. Massouras. Small Ruminant Research. Volume 113, Issues 2-3, July 2013, Pages 446-453. DOI https://doi.org/10.1016/j.smallrumres.2013.04.009.

7. Nagovska V., Hachak Y., Gutyj B., Bilyk O., Slyvka N. Influence of wheat bran on quality indicators of a sour milk beverage. Eastern-European Journal of Enterprise Technologies. 2018. Vol. 4, Issue 11 (94). P. 28-34.

8. Sadowska-Rociek, A. Assessment of nutrient content in selected dairy products for compliance with the nutrient content claims / A. Sadowska-Rociek, B. Mickowska, E. Cieślik. Journal of Microbiology, Biotechnology and Food Sciences. 2013; 2(Special issue):1891-1897

9. Samilyk M. Improving the technology of soft sour milk cheese by increasing biological value. Scientific Messenger of Lviv National University of Veterinary Medicine and Biotechnologies. 2017. Vol. 19, № 80. P. 33-37. 
10. Turchyn I., Zalensky, M., Voychishin, A. Development of technology of cereal past with combined composition. Scientific Messenger of Lviv National University of Veterinary Medicine and Biotechnologies. 2018. Vol. 20, № 85. P. 24-28.

11. Беницька А.а., Осечко в.І., Гачак Ю.Р. Спеції в якості фітодобавок у технології молочних продуктів ЛПС. Матеріали міжнародної студентського наукової конферениії ЛНУВМ БТ імені С. з. Гжицького. 2016. Ч. 3. С. 89-90.

12. Бойчак Я. Кобернюк В., Петрик Л. Нові види і форми біодобавок в технології молочних продуктів ЛПН. Дні студентської науки у ЛНУВМ та БТ імені С.З. Гжииького: Матеріали студентської конферениії. Львів, 2018. С. 79-80.

13. Гачак Ю.Р., Михайлицька О.Р. Застосування рослинної біодобавки в технології плавлених сирів. Збірник матеріалів наукової конферениіі «Оздоровчі харчові продукти та дієтичні добавки: технології, якість та безпека». Київ : НУХТ, 2014. С. 31-32.

14. Гойко I., Пришепа М. Застосування кропу, черемші, базиліку у виробництві кисломолочного сиру. Збірник міжнародної науково-практичної конферениії «Оздоровчі харчові продукти та дієтичні добавки, технології, якість та безпека». Київ : НУХТ, 2014. C. $15-16$.

15. Грек О.В., Скорченко Т.а. Технологія комбінованих продуктів на молочній основі : підручник / НУХТ. Київ, 2012. 362 с.

16. Ільїнська А., Беницька А., Пристанський Р. Кріопорошки в якості біодобавок у молочних продуктах ЛПН. Актуальні задачі сучасних технологій : збірник тез доповідей н. m. конферениії молодих учених та студентів. Тернопіль, 2017. С. 174-175.

17. Мазараки А.А., Пересічний М.і., Кравченко М.Ф. Технологія продуктів функціонального призначення. Київ, Київ. нац. торг.-екон. універстет. 2012. 116 с.

18. Мусульманова М.М. Комбинированные молочнорастительные продукты. Молочная промышленность. 2006. № 5. C. $72-73$.

19. Пуківський П., Турчин I., Сливка Н., Михайлицька О. Використання рослинної сировини в технології сиркових мас. Науковий вісник Львівського національного університету ветеринарної медицини та біотехнологій імені С. З. Гжицького. 2015. T. 17, № 4. C. 105-109.

20. Савченкова Л.В. Немятих О.Д., Тернинко I.I., Рокотянська В.В., Акімова М.С., Бурцева О.М., Кулдиркаєва Є.В. Лікарські рослини як джерело створення нових лікарських засобів / Луганськ : СПД Рєзнік В.С., 2012. 64 с. 
21. Савченкова Л.В., Акімова М.С. Вивчення токсичності кріоподрібненого порошку аронії чорноплідної. Аспекти розвитку фармачевтичних та медичних досліджень на сучасному етапі: матеріали IV Всеукраїнської науково-практичної конферениії 3 міжнародною участю, м. Луганськ, 27-28 березня 2014 р. С. 105.

22. Сирохман I.B., Загородня в.М. Товарознавство продуктів функціонального призначення : навч. посібник для студентів ВНЗ. Київ, 2009. 544 с.

23. Сливка Н.Б. Нова рецептура плавлених сирів із ехінацеєю та страв $з$ нього. Тези доповідей Всеукраӥнської науково-практичної конференції мол. вчених і студентів «Актуальні питання розвитку харчових в-в, ресторанного г-ва і торгівлі». Харків. 2010. С. 27-89.

24. Сязин И.Е., Касьянов Г.И. Техника и технология криообработки пищевого сырья: монография. Часть І. Краснодар : Экоинвест, 2011. 157 с.

25. Украинец А.И., Рашевская Т.А., Вашека О.Н. Морфология кристаллических элементов наноструктуры сливочного масла с криопорошками растительными пищевыми. Кинетика и механизм кристаллизации. Кристаллизация для нанотехнологий, техники и медицины : V междунар. науч. конф., 23-26 сент. 2008 г.: тезисы докл. Иваново (Россия), 2008. С. 190.

26. Лісовська Ю., Пунейко О. Розробка рецептур молочних продуктів ЛПН із кріопорошком із морепродуктів. Дні студентської науки у ЛНУВМ та БТ імені С.З. Гжицького : Матеріали студентської конференції. Львів, 2018. С. 110-111.

\section{Information about authors:} Hachak Yu. R.,

Candidate of Biological Sciences, Associate Professor at the Department of Technology of Milk and Milk Products Stepan Gzhytskyi National University of Veterinary Medicine and Biotechologies Lviv 50, Pekarska str., Lviv, 79010, Ukraine

Gutyj B. V., Doctor of Veterinary Science, Professor at the Department of Pharmacology and Toxicology Stepan Gzhytskyi National University of Veterinary Medicine and Biotechologies Lviv 50, Pekarska str., Lviv, 79010, Ukraine 